Prepared in cooperation with the Bureau of Land Management, U.S. Fish and Wildlife Service, Great Basin Landscape Conservation Cooperative, and Ada County Soil and Water Conservation District

\title{
An Experimental Test of Weed-Suppressive Bacteria Effectiveness in Rangelands in Southwestern Idaho, 2016-18
}

Open-File Report 2019-1050

U.S. Department of the Interior

U.S. Geological Survey 
Cover: Photograph showing rangeland at Wildcat study site, southwestern Idaho. Photograph by Brynne Lazarus, U.S. Geological Survey, May 30, 2017. 


\section{An Experimental Test of Weed-Suppressive Bacteria Effectiveness in Rangelands in Southwestern Idaho, 2016-18}

By Brynne E. Lazarus and Matthew J. Germino

Prepared in cooperation with the Bureau of Land Management, U.S. Fish and Wildlife Service, Great Basin Landscape Conservation Cooperative, and Ada County Soil and Water Conservation District

Open-File Report 2019-1050 


\section{U.S. Department of the Interior \\ DAVID BERNHARDT, Secretary}

\section{U.S. Geological Survey James F. Reilly II, Director}

U.S. Geological Survey, Reston, Virginia: 2019

For more information on the USGS-the Federal source for science about the Earth, its natural and living resources, natural hazards, and the environment-visit https://www.usgs.gov/ or call 1-888-ASK-USGS.

For an overview of USGS information products, including maps, imagery, and publications, visit https:/store.usgs.gov.

The findings and conclusions in this report are those of the authors and do not necessarily represent the views of the U.S. Fish and Wildlife Service.

Any use of trade, firm, or product names is for descriptive purposes only and does not imply endorsement by the U.S. Government.

Although this information product, for the most part, is in the public domain, it also may contain copyrighted materials as noted in the text. Permission to reproduce copyrighted items must be secured from the copyright owner.

Suggested citation:

Lazarus, B.E., and Germino, M.J., 2019, An experimental test of weed-suppressive bacteria effectiveness in rangelands in southwestern Idaho, 2016-18: U.S. Geological Survey Open-File Report 2019-1050, 19 p., https://doi.org/10.3133/ofr20191050.

ISSN 2331-1258 (online) 


\section{Contents}

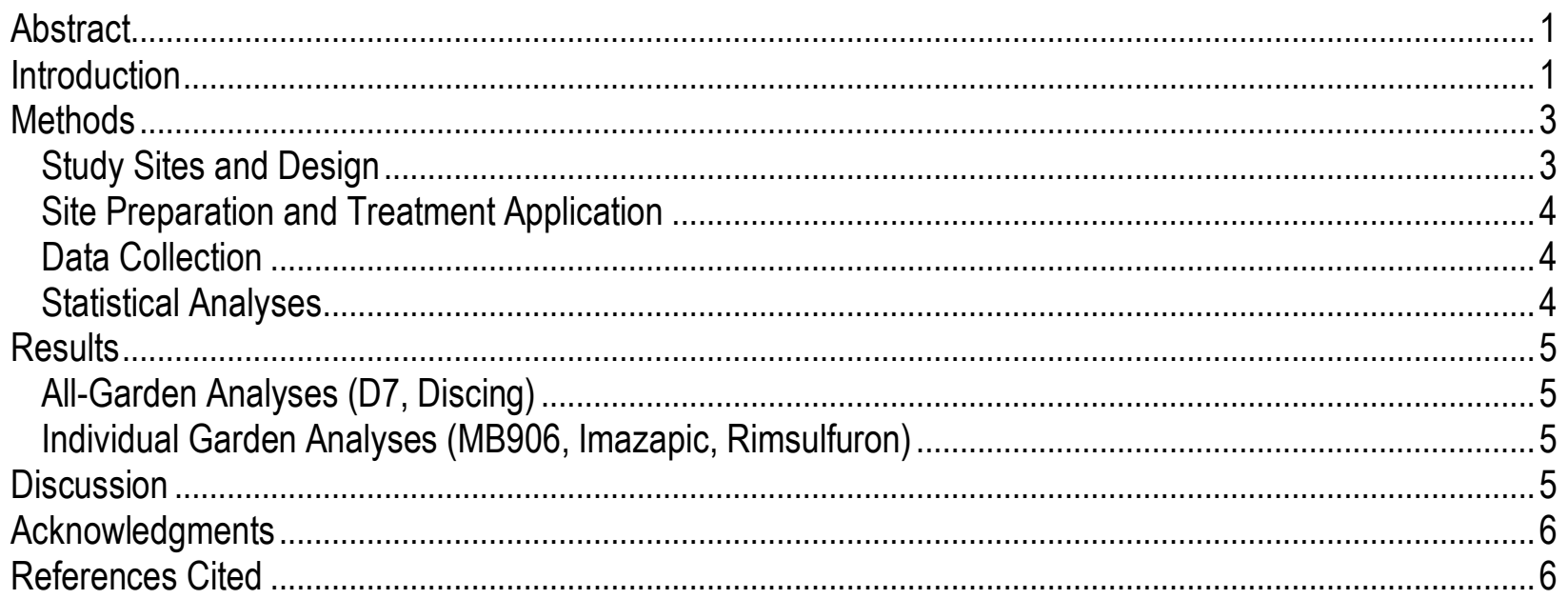

\section{Figures}

Figure 1. Image showing Wildcat, Avimor, and Orchard study site locations, southwestern Idaho, 2016

Figure 2. Experimental design of treatments applied at Wildcat, Orchard, and Avimor study sites, southwestern Idaho, autumn 2016.

Figure 3. Graphs showing cover of the whole plant community, or of the annual grasses that were previously reported to be affected by weed-suppressive bacteria, and perennial grasses for all three study sites combined, southwestern Idaho, 2016-18...

Figure 4. Graphs showing total community foliar cover by Wildcat, Orchard, and Avimor study sites, southwestern Idaho, 2016-18

Figure 5. Graphs showing cover of invasive annual grasses targeted by weed-suppressive bacteria by Wildcat, Orchard, and Avimor study sites, southwestern Idaho, 2016-18.

Figure 6. Graphs showing perennial grass cover by Wildcat, Orchard, and Avimor study sites, southwestern Idaho, 2016-18

Figure 7. Photographs showing representative plots at the Wildcat, Orchard, and Avimor study sites, southwestern Idaho.

\section{Tables}

Table 1. Elevation, climate, soil texture and type, ownership, and plant community data at Wildcat, Avimor, and Orchard study sites, southwestern Idaho.

Table 2. Weed-suppressive treatments applied at the three study sites, southwestern Idaho, autumn 2016

Table 3. Results of analysis of variance testing effects of site and treatment on total foliar cover, invasive annual grass cover, and perennial bunchgrass cover at Wildcat, Avimor, and Orchard study sites, southwestern Idaho.

Table 4A. Planned linear contrasts in total foliar cover by study site, southwestern Idaho, spring $2018 \ldots . .17$

Table 4B. Planned linear contrasts in cover of invasive annual grasses targeted by weed-suppressive bacteria by study site, southwestern Idaho, 2018

Table 4C. Planned linear contrasts in cover of perennial grasses by study site, southwestern Idaho, spring 2018. 


\section{Conversion Factors}

U.S. customary units to International System of Units

\begin{tabular}{|c|c|c|}
\hline Multiply & By & To obtain \\
\hline \multicolumn{3}{|c|}{ Length } \\
\hline foot $(\mathrm{ft})$ & 0.3048 & meter $(\mathrm{m})$ \\
\hline \multicolumn{3}{|c|}{ Area } \\
\hline acre & 4,047 & square meter $\left(\mathrm{m}^{2}\right)$ \\
\hline acre & 0.4047 & hectare (ha) \\
\hline \multicolumn{3}{|c|}{ Volume } \\
\hline ounce, fluid (fl. oz.) & 0.02957 & liter (L) \\
\hline gallon (gal) & 3.785 & liter $(\mathrm{L})$ \\
\hline
\end{tabular}

International System of Units to U.S. customary units

\begin{tabular}{lcl}
\hline \multicolumn{1}{c}{ Multiply } & By & To obtain \\
\hline centimeter $(\mathrm{cm})$ & Length & \\
meter $(\mathrm{m})$ & 0.3937 & inch (in.) \\
\hline & 3.281 & foot (ft) \\
\hline square kilometer $\left(\mathrm{km}^{2}\right)$ & Area & acre \\
square kilometer $\left(\mathrm{km}^{2}\right)$ & 247.1 & square mile $\left(\mathrm{mi}^{2}\right)$ \\
\hline & 0.3861 & \\
\hline $\mathrm{g}($ gram $)$ & Mass & ounce(oz) \\
\hline
\end{tabular}

\section{Abbreviations}

ANOVA

analysis of variance

DIMA

pf

Database for Inventory Monitoring and Assessment

WSB

Pseudomonas fluorescens

weed-suppressive bacteria 


\title{
An Experimental Test of Weed-Suppressive Bacteria Effectiveness in Rangelands in Southwestern Idaho, 2016-18
}

\author{
By Brynne E. Lazarus and Matthew J. Germino
}

\section{Abstract}

Approaches and techniques for control of exotic annual grasses are a high priority in sagebrush-steppe and other rangelands. Strains of the soil bacterium Pseudomonas fluorescens (Pf) have been proposed to be selectively pathogenic to multiple species of exotic annual grasses with effects evident by the second year, and with no effect on native or desirable species including native bunchgrasses. However, scientifically defensible tests of the target and nontarget/risk effects of these hypothetically weed-suppressive bacteria (WSB) strains in the field have been lacking in rangelands and other environments. We evaluated the effects of two strains of Pf WSB (D7 and MB906) sprayed on the surface in autumn 2016 at three sites in sagebrush steppe across southwestern Idaho that had cheatgrass (Bromus tectorum), medusahead (Taeniatherum caput-medusae), and other exotic annual grasses. Treatments also were replicated within each site $(n=3,8.3 \times 8.3$ meter plots) and included evaluation of the WSB strains with and without herbicides (imazapic and rimsulfuron) and with or without discing to mix surface-spray of the WSB into deeper soils. By the second year following application (spring 2018), neither strain of WSB affected exotic annual grasses, perennial bunchgrasses, or total community cover, either with WSB alone or in combination with herbicides or discing. We conclude that neither the D7 nor MB906 strains of Pf WSB have a negative effect on exotic annuals at the sites we evaluated.

\section{Introduction}

Exotic annual grasses are affecting numerous ecosystem types, particularly semiarid rangelands such as sagebrush steppe, where they are causing increased wildfire activity, loss of biotic diversity, and diminished ecosystem services on about one-half of the approximately 1 million $\mathrm{km}^{2}$ of the original range of the habitat type (Miller and others, 2011). Once exotic annual grasses dominate a site, it is very difficult to restore the native species assemblage and abundance using current approaches (Monaco and others, 2017). This difficulty is due partly to strong feedbacks that exotic annuals have on the environment (for example, disturbance patterns, soils, nutrient cycling) that directly enhance their own establishment but also diminish the competitive ability of displaced species (Germino and others, 2016). Management strategies and techniques that can be used to prevent plant communities from becoming dominated by exotic 
annual grasses are a priority for land managers. Management actions that increase the resistance of sites to invasion by exotic annual grasses, and their resilience to disturbances (ability to recover quickly) are increasingly used. Preserving or restoring resprouting bunchgrasses, which generally are better able to compete with exotic annuals (Chambers and others, 2016), is considered central to sustaining or increasing the resistance and resilience of a native plant community.

Where sites are co-dominated by bunchgrasses and exotic annuals, there is a particular need for treatments to reduce competition to bunchgrasses from exotic annual grasses and thereby increase bunchgrass populations. Although pre-emergent herbicides can be used to diminish exotic annuals without effects on bunchgrasses (for example, Applestein and others, 2018), their effectiveness is short-lived, generally less than 2 years. Population growth of bunchgrasses (maturity of existing individuals plus new recruits) typically requires longer time frames, such as multiple years to a decade in the warmest and driest sites within sagebrush steppe where exotic annuals are most problematic. Thus, a tool of high value to land managers would be one that can provide sustained control of exotic annual grasses after the initial action of herbicides (or perhaps in place of herbicides) for 2-5 years while bunchgrass populations become better established.

Most or all plant species are subject to pathogens, although the rapid expansion of exotic plant species as they invade new areas often results in escape from their natural "enemies" (Blumenthal, 2005). Biocontrol agents, including invertebrates and microbes, have been identified and used successfully on many exotic species including exotic invasive forbs in rangelands. Exotic annual grass communities, like most low-diversity grass stands (for example, wheat fields), are known to be periodically prone to pathogenically driven stand failure (Hulbert, 1955). A complex of five soil/plant fungal species are known to interact in ways that cause "cheatgrass dieoff" at large scales, and although the biology and ecology of the phenomenon are well known, dispersion of the fungi does not seem feasible in such as manner as to induce predictable dieoffs (Meyer and others, 2016). A less-well-studied but more strongly endorsed biocontrol prospect has emerged with strains of the widespread bacterium Pseudomonas fluorescens $(\mathrm{Pf})$, which has reportedly reduced root growth in laboratory, greenhouse, and wheat field trials of exotic annual grasses including Bromus tectorum (cheatgrass), Taeniatherum caput-medusae (medusahead), and Aegilops cylindrica (jointed goat grass), but has had no effect on a long list of native or agriculturally important species (Kennedy and others, 1991, 2001; Johnson and others, 1993; Kennedy and Stubbs, 2007; Kennedy, 2018). Only one report of the effectiveness of the bacteria in rangelands is available (Kennedy, 2018; strain ACK55), and although the report showed very high levels of control from the first growing season following application to more than 5 years after application, report data are insufficient to determine whether the results are reproducible. Numerous other trials have been implemented but few have all the components of replication, proper controls, and quantitative measurement of vegetation responses.

The appeal of Pf weed-suppressive bacteria (WSB) is that it is considered nativealthough the species is known to be very diverse and thus local adaptation seems very likelyand can be dried and rehydrated for relatively inexpensive spraying across large landscapes at low densities. The bacterium supposedly requires cool, wet conditions for significant population growth, and the concept is that late autumn application of small quantities of Pf WSB is followed by growth increase in soils to levels pathogenic to exotic annual grasses. Soil surfaces in sagebrush steppe can have extreme growth conditions for bacteria owing to large temperature 
variation, low moisture, and low nutrient availability. Whether incorporating surface soils in deeper horizons that have more favorable growth conditions would enhance any potential effects of Pf WSB is an important question for its application in sagebrush steppe. Co-application of WSB with herbicides also is an attractive management option, and whether WSB effects interact positively or negatively with herbicides is another key question (especially because early trials only tested the combined effects of herbicide and WSB rather than taking a factorial approach).

In this study, we tested the efficacy for annual weed control of two P. fluorescens strains, two application methods (surface spraying and incorporation by discing), and application in combination with two herbicides (imazapic and rimsulfuron) for three southwestern Idaho sites differing in climate, soils, and plant community. Three dominant strains of Pf WSB were available at the inception of this study (and still are in various ways):

1. ACK55, which is not permitted for use on public lands and was not available at the inception of the experiment;

2. D7, which was shown to be effective against cheatgrass or jointed goatgrass in the laboratory, greenhouse, and wheat fields (Kennedy and others, 1991, 2001; Johnson and others, 1993; Kennedy and Stubbs, 2007) and is a registered biopesticide in the United States and at the time was commercially available through Verdesian Life Sciences; and

3. MB906, which was commercially available as a soil amendment through Bio-West Inc. but was not permissible for use on Federal land.

Bio-West Inc. has since removed the MB906 product from the market and is planning release of a similar, registered product.

\section{Methods}

\section{Study Sites and Design}

The study was replicated at three southwestern Idaho sites differing in climate, soils, and vegetation community (fig. 1, table 1). The Wildcat site, the lowest and driest of the three sites, is located on state grazing land near Marsing, Idaho, and was shrub steppe occupied primarily by shadscale saltbush (Atriplex confertifolia) before it burned during the 2015 Soda Fire. A subsequent drill seeding with crested wheatgrass (Agropyron cristatum) was initially unsuccessful, and the site was occupied primarily by cheatgrass and Sandberg bluegrass (Poa secunda) at the time of treatment initiation in autumn 2016. The Orchard site, intermediate in elevation and precipitation, is located east of Bureau of Land Management Birds of Prey National Conservation Area in an area without cattle grazing for many years but that is heavily used by smaller herbivores. At the time of treatment initiation, the Orchard plant community consisted primarily of crested wheatgrass, cheatgrass, and sixweeks fescue (Vulpia octoflora), a native annual grass. The highest and wettest of the three sites, Avimor, is on private easement land in the Boise foothills. At the time of treatment initiation, the Avimor plant community consisted primarily of the warm-season perennial bunchgrass three-awn (Aristida purpurea) and several invasive annual grasses - primarily medusahead and Ventenata dubia but also field brome (Bromus arvensis), cheatgrass, and rattail fescue (Vulpia myuros), and the invasive biennial bulbous bluegrass (Poa bulbosa). MB906 treatments could not be applied at the Orchard site because MB906 has not been approved for use on Federal lands. 


\section{Site Preparation and Treatment Application}

Treatment application occurred in autumn 2016. Sites were fenced to exclude grazing and pre-burned to simulate post-fire conditions and to allow the bacteria to make contact with the soil. Herbicides were applied in October. Each of the 10 treatments (table 2) was randomly applied in three replicate $25 \times 25$-ft plots at each site (fig. 2). Herbicides and bacteria were sprayed with a pressured hose and dye to ensure even application. Imazapic was applied at a rate of $6 \mathrm{oz} /$ acre with $24 \mathrm{oz} /$ acre of the adjuvant methylated seed oil (MSO) in $100 \mathrm{gal} /$ acre of water. Rimsulfuron was applied at $4 \mathrm{oz} /$ acre with $24 \mathrm{oz} /$ acre MSO in 100 gal/acre of water. Bacteria were applied in November, when temperatures were cool and conditions were moist. D7 (freeze dried) was resuspended in tap water and applied at a rate of $2 \mathrm{~g} / \mathrm{acre}$ in $100 \mathrm{gal} / \mathrm{acre}$ of water. MB906 was received as a liquid suspension of live cells and was applied at a rate of 1 gal/acre in $100 \mathrm{gal} /$ acre of water. Bacteria and herbicide could not be co-applied simultaneously because the weather conditions and phenological response of exotic annuals occurred earlier in autumn (thus requiring spraying earlier) than the time at which conditions were optimal for the spraying of bacteria. Discing treatments occurred following bacterial application with a mini rangeland drill pulled by an all-terrain vehicle.

\section{Data Collection}

Data collection occurred (1) prior to treatment (September 2016), (2) in year 1 spring (May-June 2017), and (3) in year 2 spring (May-June 2018). We measured foliar cover using Line Point Intercept (Herrick and others, 2009) in $1 \times 0.5-\mathrm{m}$ frames $(36$ points per frame $\times 5$ frames per plot $=180$ points per plot at each collection interval). A pin was dropped at each point on the frame, and all species touching the pin from the canopy down to the soil surface were recorded. The presence of litter and the condition of the surface (for example, soil, rock, gravel, lichen crust) also were recorded. Data were entered directly into a DIMA database (Database for Inventory Monitoring and Assessment, Jornada Experimental Range, New Mexico) in the field using a Mesa ${ }^{2}$ field tablet (Juniper Systems, Logan, Utah). The cover values we report include the subcanopy (that is, "any hit" rather than "first hit" in DIMA).

\section{Statistical Analyses}

We used analysis of variance (ANOVA) to determine treatment effects on 2018 (year 2 spring, which provided the most amount of time for treatments to become evident) total foliar cover, cover of invasive annual grasses targeted by WSB (cheatgrass and medusahead), and perennial grass cover. For treatments that were applied at all sites and did not show site $\mathrm{x}$ treatment interactions in preliminary analyses (D7, discing), we analyzed all sites together using ANOVA with a full factorial with main effects site, D7, and discing as independent variables ("all-garden analyses" results in table 3). We used Tukey-Kramer analyses to understand differences among sites. For treatments that were not applied at all sites (MB906), or that showed significant site $\mathrm{x}$ treatment interactions in preliminary analyses (imazapic, rimsulfuron), we calculated ANOVAs for individual sites with "treatment" as the independent variable and then used planned linear contrasts to investigate treatment differences ("individual garden analyses" results in table 4A-4C). Invasive annual grass cover was arcsine square root transformed to homogenize variance. All analyses were completed in JMP 12.1.0 (SAS Institute, Cary, North Carolina). 


\section{Results}

\section{All-Garden Analyses (D7, Discing)}

The application of D7, either as a surface spray or incorporated with discing, did not decrease total foliar cover or cover of invasive annual grasses targeted by WSB, nor did it increase perennial grass cover for the three sites in year 2 spring (table 3, fig. 3). Discing (with or without D7) resulted in lower total foliar cover at the Orchard site only (significant site $\mathrm{x}$ discing interaction; see table 3 and fig. 4). Sites varied significantly in cover - cover of annual grasses targeted by WSB was highest at Wildcat, intermediate at Orchard, and lowest at Avimor (fig. 5); perennial grass cover was higher at Avimor than at the other two sites (fig. 6). Cover averages for the three gardens combined for all treatments and all years are plotted in figure 3. Cover averages for individual gardens for all treatments and all years are plotted in figures 4-6.

\section{Individual Garden Analyses (MB906, Imazapic, Rimsulfuron)}

The application of MB906, either as a surface spray or incorporated with discing, did not decrease total foliar cover or cover of invasive annual grasses targeted by WSB, nor did it increase perennial grass cover at any of the three sites in year 2 spring (table $4 \mathrm{~A}-4 \mathrm{C}$; figs. 4-6). Imazapic decreased total foliar cover and cover of invasive annual grasses targeted by WSB but did not increase perennial grass cover for all three sites in year 2 spring (table 4A-4C; figs. 4-6). The effect of imazapic was not modified in any way by additional application of D7 (table 4A4C; figs. 4-6).

Rimsulfuron decreased total foliar cover substantially at Orchard, slightly at Avimor, and did not decrease total foliar cover at Wildcat in year 2 spring (table 4A; fig. 4). Rimsulfuron decreased cover of invasive annual grasses targeted by WSB at Avimor and Orchard but not at Wildcat in year 2 spring (table 4B; fig. 5), although it did reduce annual grass cover strongly at all three sites in year 1 spring (fig. 5; statistics not shown). Rimsulfuron significantly decreased perennial grass cover (primarily Poa secunda) at Wildcat but did not affect perennial grass cover at the other two sites (table 4C; fig. 6). The effect of rimsulfuron was not modified in any way by additional application of D7 (table 4A-4C; figs. 4-6).

\section{Discussion}

According to Kennedy (2018), WSB effects can be pronounced by years 1 and 2 after spraying. However, neither strain of WSB led to decreases in targeted invasive annual grasses or increases in perennial grass cover when sprayed on the surface, incorporated into the soil by discing, or combined with herbicide (although herbicide was effective; see fig. 7) by year 2, when at least some effect ought to be visible according to other reports (Kennedy and others, 1991; Kennedy 2018). Our application methods carefully followed guidelines regarding the freshness and viability of WSB and highly suitable cool/wet conditions prevailed during and after our applications of the treatments; thus, faulty application likely did not cause the observed results. WSB populations possibly did not increase in soils after our application to levels that can be pathogenic, and efforts are underway to determine whether detectable changes to the soil microbial community have occurred, and whether molecular genetic markers can be developed to enable us to track the WSB strains in soil after application. 
There is a slight chance that WSB effects may become evident in upcoming years, and we intend to continue measurements though the fifth post-treatment year. Of the approximately 1 million $\mathrm{km}^{2}$ of sagebrush steppe that once were present, about one-half are currently invaded by exotic annual grasses (Germino and others, 2016). These areas, both invaded and not invaded, span a wide range of soil and climate conditions (for example, mean annual precipitation ranging from 170 to $400 \mathrm{~cm} / \mathrm{yr}$, with none to nearly one-half of annual precipitation occurring in summer). The sites we studied spanned a wide range of climate (and, specifically, precipitation) conditions, although even wetter conditions than we evaluated may be necessary for WSB to have effects. In comparison to WSB, imazapic continued to be effective in controlling invasive annual grasses at all sites in year 2, whereas the decreases in annual grasses through application of rimsulfuron appeared to be lessening considerably by year 2, particularly at the driest site we studied. These interim findings suggest that imazapic can more reliably lead to short-term control of annual grasses than WSB or rimsulfuron.

\section{Acknowledgments}

Technical input and logistical support were provided by the Idaho Sage Grouse Action Team, Ada County (Idaho) Soil and Water Conservation District, Idaho Department of Lands, Idaho Department of Fish and Game, U.S. Fish and Wildlife Service, The Idaho Governor's Office for Species Conservation, The Nature Conservancy (TNC), the U.S. Geological Survey Ecosystems Mission Area, and the Bureau of Land Management (BLM) directly through the Great Basin Landscape Conservation Cooperative. Special thanks to Bas Hargrove (TNC) for lead organization in the initial stages of project conception and planning, Steve Jirik (BLM) for coordination and support from the BLM, and Michael Pellant (BLM, retired) and Joseph Milan (BLM) for comments on this report.

\section{References Cited}

Applestein, C., Germino, M.J., and Fisk, M., 2018, Vegetative community response to landscape-scale, post-fire herbicide (imazapic) application: Invasive Plant Science and Management, v. 11, no. 3, p. 127-135, https://doi.org/10.1017/inp.2018.18.

Blumenthal, D., 2005, Interrelated causes of plant invasion: Science, v. 310, no. 5746, p. $243-$ 244.

Bouyoucos, G.J., 1962, Hydrometer method improved for making particle size analyses of soils: Agronomy Journal, v. 54, no. 5, p.464-465.

Chambers, J.C., Germino, M.J., Belnap, J., Brown, C.S., Schupp, E.W., and St. Clair, S.B., 2016, Plant community resistance to invasion by Bromus species-The roles of community attributes, Bromus interactions with plant communities, and Bromus traits, in Germino, M.J., Chambers, J.C., and Brown, C.S., eds., Exotic brome-grasses in arid and semiarid ecosystems of the Western US - Causes, consequences, and management implications: Switzerland, Springer International, p. 275-304.

Germino, M.J., Belnap, J., Stark, J.M., Allen, E.B., and Rau, B.M., 2016, Ecosystem impacts of exotic annual invaders in the genus Bromus, in Germino, M.J., Chambers, J.C., and Brown, C.S., eds., Exotic brome-grasses in arid and semiarid ecosystems of the Western US - Causes, consequences, and management implications: Switzerland, Springer International, p. 61-95. 
Herrick and others, 2009, Monitoring manual for grassland, shrubland and savanna ecosystems (2d ed.), Volume 1-Quick start: U.S. Department of Agriculture-Agricultural Research Service Jornada Experimental Range, Las Cruces, New Mexico, 36 p., jornada.nmsu.edu/sites/jornada.nmsu.edu/files/Quick_Start.pdf.

Hulbert, L.C., 1955, Ecological studies of Bromus tectorum and other annual bromegrasses: Ecological Monographs, v. 25, no., 2, p. 181-213, https://doi.org/10.2307/1943550.

Johnson, B.N., Kennedy, A.C., and Ogg, A.G., 1993, Suppression of downy brome growth by a rhizobacterium in controlled environments: Soil Science Society of America Journal, v. 57, no. 1, p. 73-77.

Kennedy, A.C., 2018, Selective soil bacteria to manage downy brome, jointed goatgrass, and medusahead and do no harm to other biota: Biological Control, v. 123, p. 18-27, https://doi.org/10.1016/j.biocontrol.2018.05.002.

Kennedy, A.C., Elliott, L.F., Young, F.L., and Douglas, C.L., 1991, Rhizobacteria suppressive to the weed downy brome: Soil Science Society of America Journal, v. 55, no. 3, p. 722-727.

Kennedy, A.C., Johnson, B.N., and Stubbs, T.L., 2001, Host range of a deleterious rhizobacterium for biological control of downy brome: Weed Science, v. 49, no. 6, p. 792-797, https://doi.org/10.1614/0043-1745(2001)049[0792:HROADR]2.0.CO;2.

Kennedy, A.C., and Stubbs, T.L., 2007, Management effects on the incidence of jointed goatgrass inhibitory rhizobacteria: Biological Control, v. 40, no. 2, p. 213-221, https://doi.org/10.1016/j.biocontrol.2006.10.006.

Meyer, S.E., Beckstead, J., and Pearce, J., 2016, Community ecology of fungal pathogens on Bromus tectorum in Germino, M.J., Chambers, J.C., and Brown, C.S., eds., Exotic bromegrasses in arid and semiarid ecosystems of the Western US-Causes, consequences, and management implications: Switzerland, Springer International, p. 193-226

Miller, R.F., Knick, S. T., Pyke, D.A., Meinke, C.W., Hanser, S.E., Wisdom, M.J., and Hild, A.L., 2011, Characteristics of sagebrush habitats and limitations to long-term conservation, in Knick, S.T., and Connelly, J., eds., Greater sage grouse-Ecology and conservation of a landscape species and its habitats-Studies in avian biology, volume 38: Berkeley, University of California Press, p. 145-184.

Monaco, T.A., Mangold, J.M., Mealor, B.A., Mealor, R.D., and Brown, C.S., 2017, Downy brome control and impacts on perennial grass abundance-A systematic review spanning 64 years: Rangeland Ecology and Management, v. 70, no. 3, p. 396-404, https://doi.org/10.1016/j.rama.2016.09.008. 


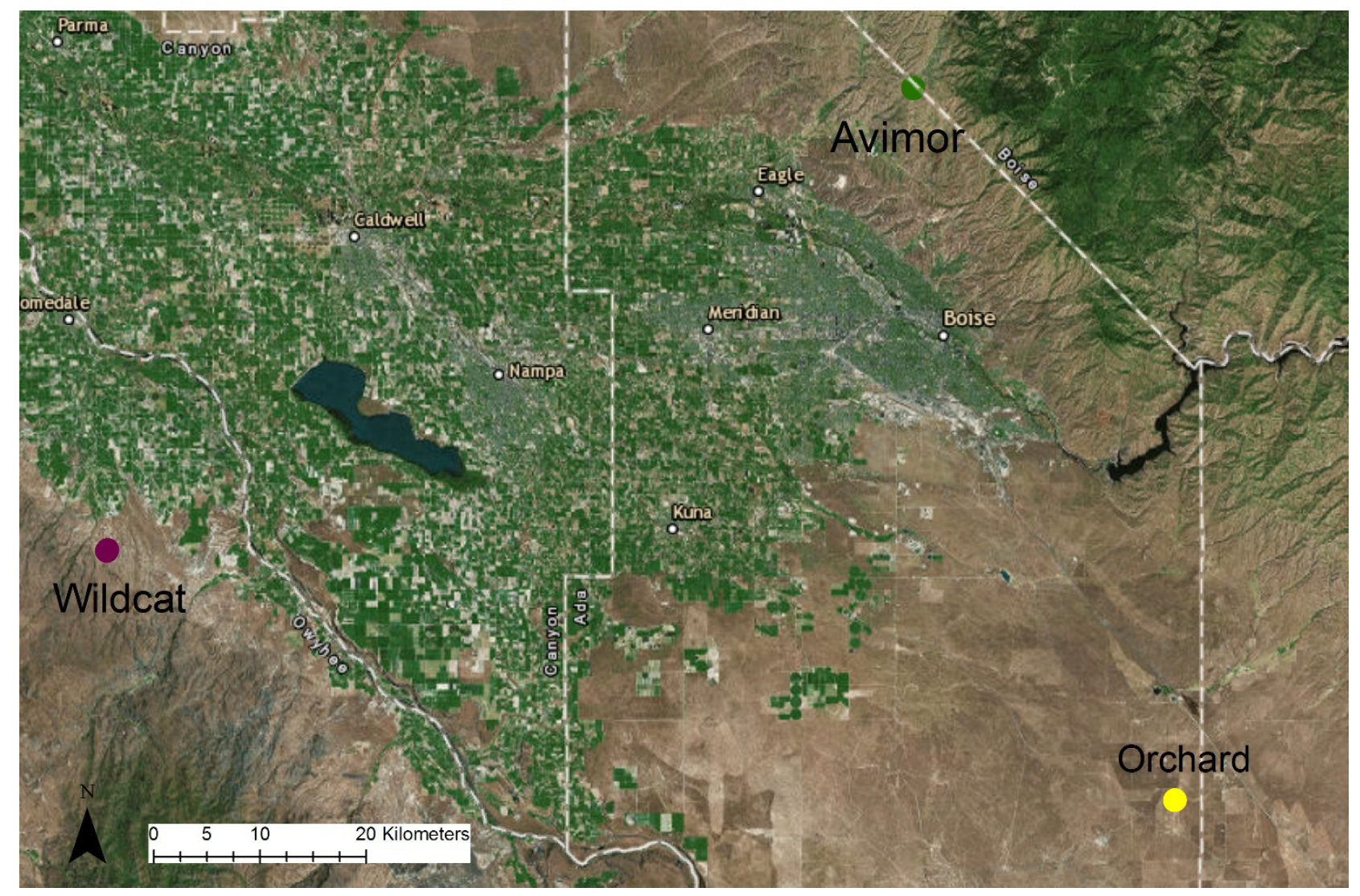

Figure 1. Image showing Wildcat, Avimor, and Orchard study site locations, southwestern Idaho, 2016. Image sources: Esri, Digital Globe, GeoEye, Earthstar Geographics, CNES/Airbus, U.S. Department of Agriculture, U.S. Geological Survey, AEx, Getmapping, Aerogrid, IGN, IGP, swisstopo, HERE, DeLorme, @OpenStreetMap contributors, and the geographic information system user community. 


\section{Wildcat}

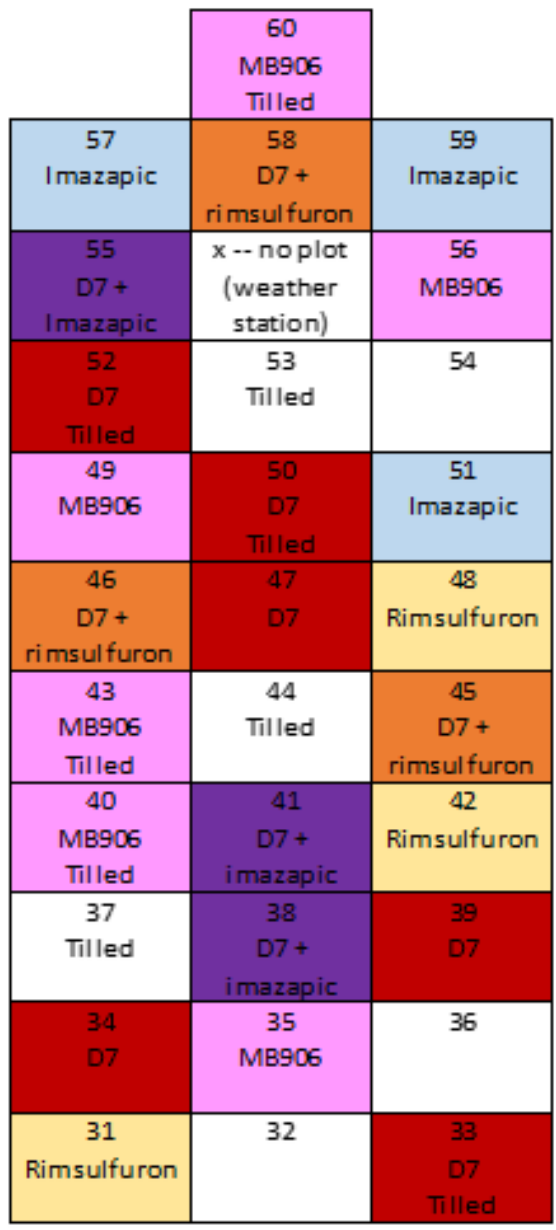

Orchard

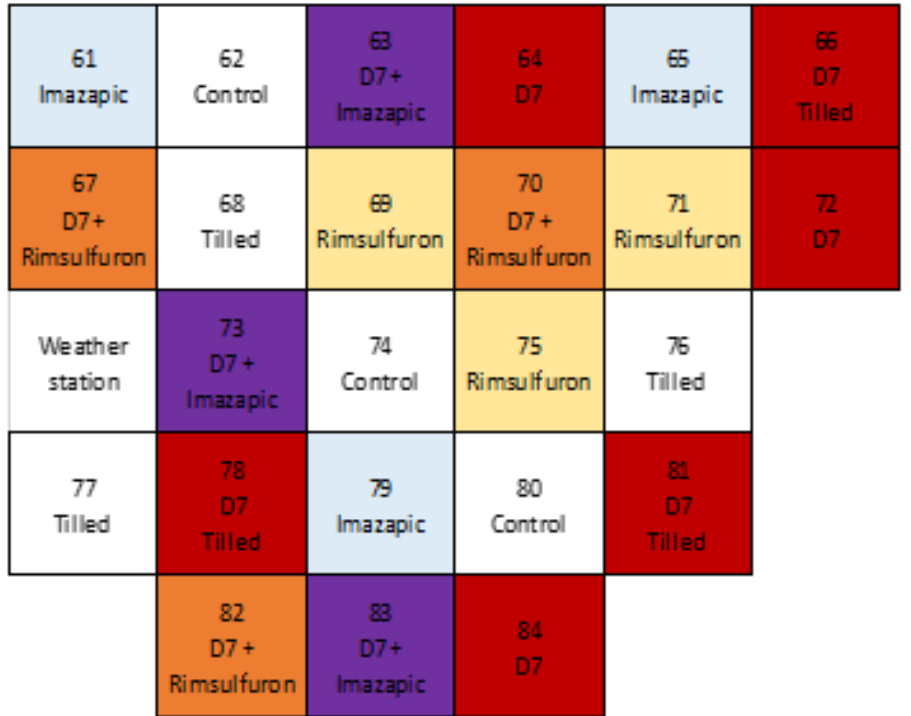

\section{Avimor}

\begin{tabular}{|c|c|c|c|c|}
\hline$x$ & $\begin{array}{c}27 \\
\text { Control }\end{array}$ & $\begin{array}{c}28 \\
\text { D7 } \\
\text { Tllled }\end{array}$ & $\begin{array}{c}29 \\
\text { MB906 }\end{array}$ & $\begin{array}{c}30 \\
\text { D7 + } \\
\text { rimsulfuron }\end{array}$ \\
\hline $\begin{array}{c}21 \\
\text { Imazapic }\end{array}$ & $\begin{array}{c}22 \\
\text { Rilmsulfuron }\end{array}$ & $\underset{\text { Imazapic }}{23}$ & $\begin{array}{c}24 \\
\text { Rilmsulfuron }\end{array}$ & $\begin{array}{c}25 \\
\text { MB906 }\end{array}$ \\
\hline & $\begin{array}{c}17 \\
\text { D7 + } \\
\text { rimsulfuron }\end{array}$ & $\begin{array}{c}18 \\
\text { MBgos } \\
\text { Tilled }\end{array}$ & $\begin{array}{c}19 \\
\text { D7 + } \\
\text { rimsulfuron }\end{array}$ & $\begin{array}{c}20 \\
\text { D7 + } \\
\text { Im az apic }\end{array}$ \\
\hline & $\begin{array}{l}13 \\
07\end{array}$ & $\begin{array}{c}14 \\
\text { Tilled }\end{array}$ & $\begin{array}{l}15 \\
07\end{array}$ & $\begin{array}{c}16 \\
\text { Im az apic }\end{array}$ \\
\hline & $\begin{array}{c}9 \\
07\end{array}$ & $\begin{array}{c}10 \\
\text { Control }\end{array}$ & $\begin{array}{c}11 \\
\text { Tilled }\end{array}$ & $\begin{array}{c}12 \\
\text { MB906 }\end{array}$ \\
\hline & $\begin{array}{c}5 \\
\text { MBgo6 } \\
\text { Tilled }\end{array}$ & $\begin{array}{c}6 \\
\text { MBgos } \\
\text { Tllled }\end{array}$ & $\begin{array}{c}7 \\
\text { D7 + } \\
\text { Imazapic }\end{array}$ & $\begin{array}{c}8 \\
\text { D7 + } \\
\text { Imazapic }\end{array}$ \\
\hline & $\begin{array}{c}1 \\
07 \\
\text { Tilled }\end{array}$ & $\begin{array}{c}2 \\
\text { Control }\end{array}$ & $\begin{array}{c}3 \\
07 \\
\text { Tilled }\end{array}$ & $\begin{array}{c}4 \\
\text { Tilled }\end{array}$ \\
\hline
\end{tabular}

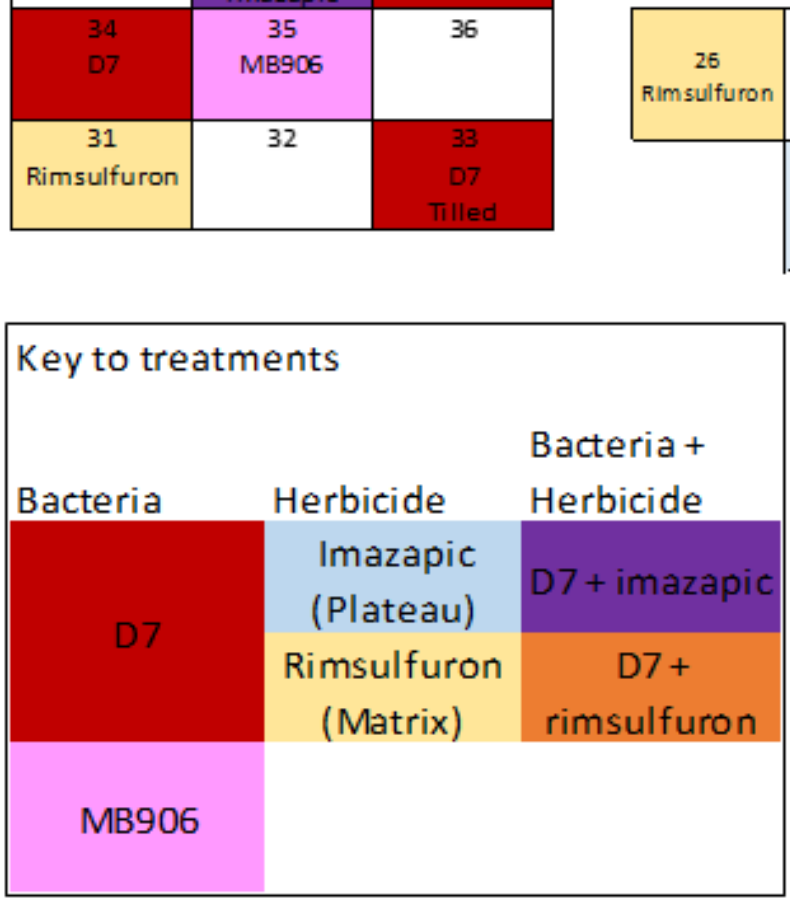

Key to treatments

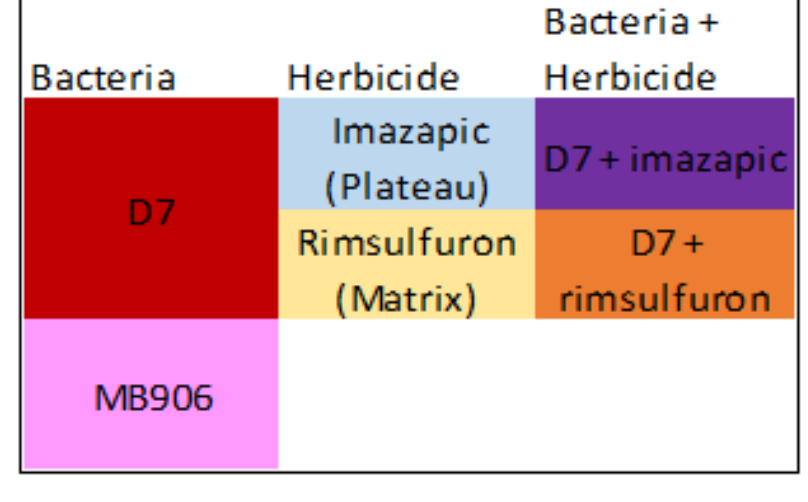

Figure 2. Experimental design of treatments applied at Wildcat, Orchard, and Avimor study sites, southwestern Idaho, autumn 2016. Plot numbers are indicated at the top of each square. 


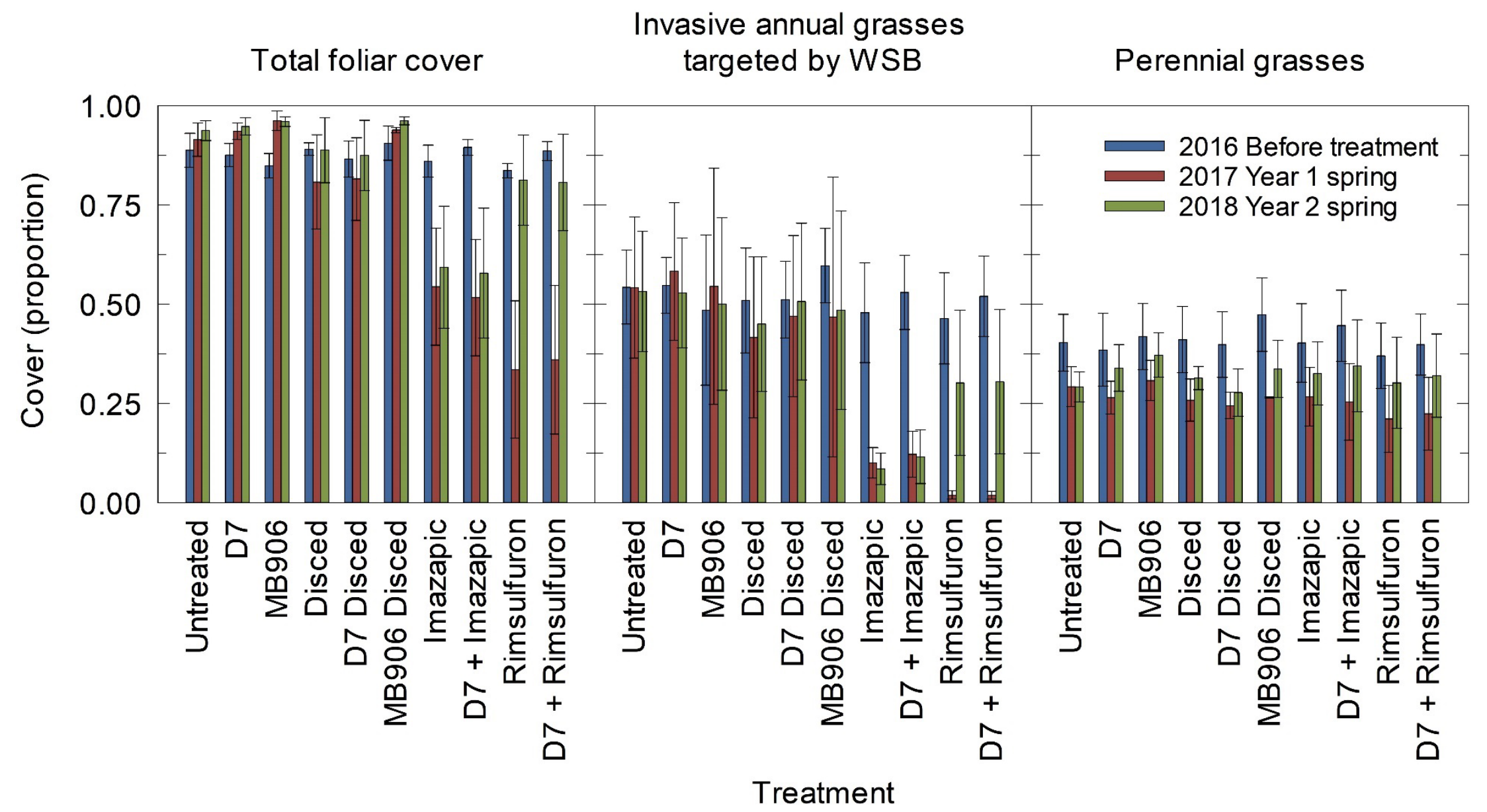

Figure 3. Graphs showing cover of the whole plant community (left graph), or of the annual grasses that were previously reported to be affected by weed-suppressive bacteria (WSB; middle graph), and perennial grasses (right graph) for all three study sites combined, southwestern Idaho, 201618. 


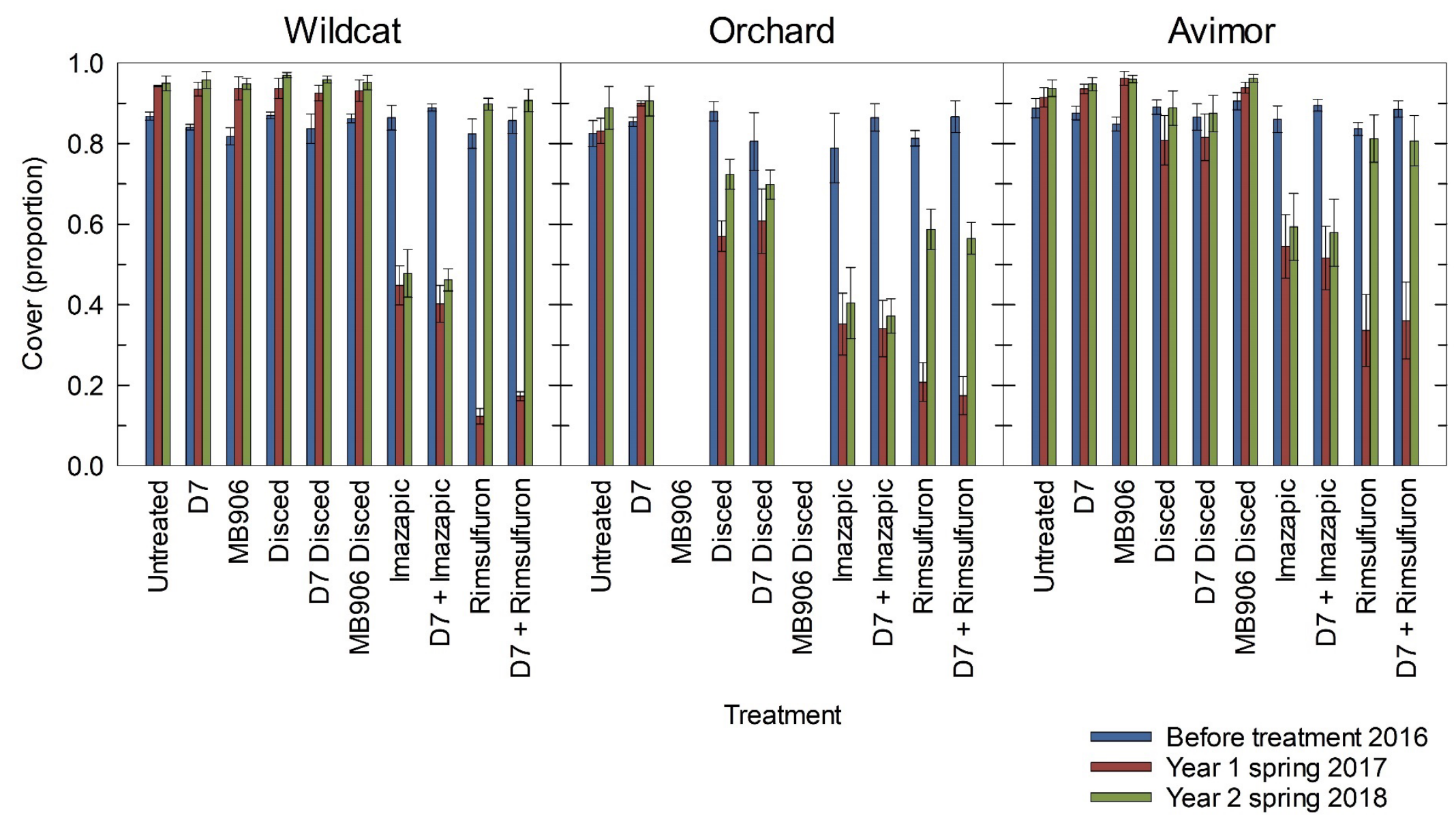

Figure 4. Graphs showing total community foliar cover by Wildcat (left graph), Orchard (middle graph), and Avimor (right graph) study sites, southwestern Idaho, 2016-18. 


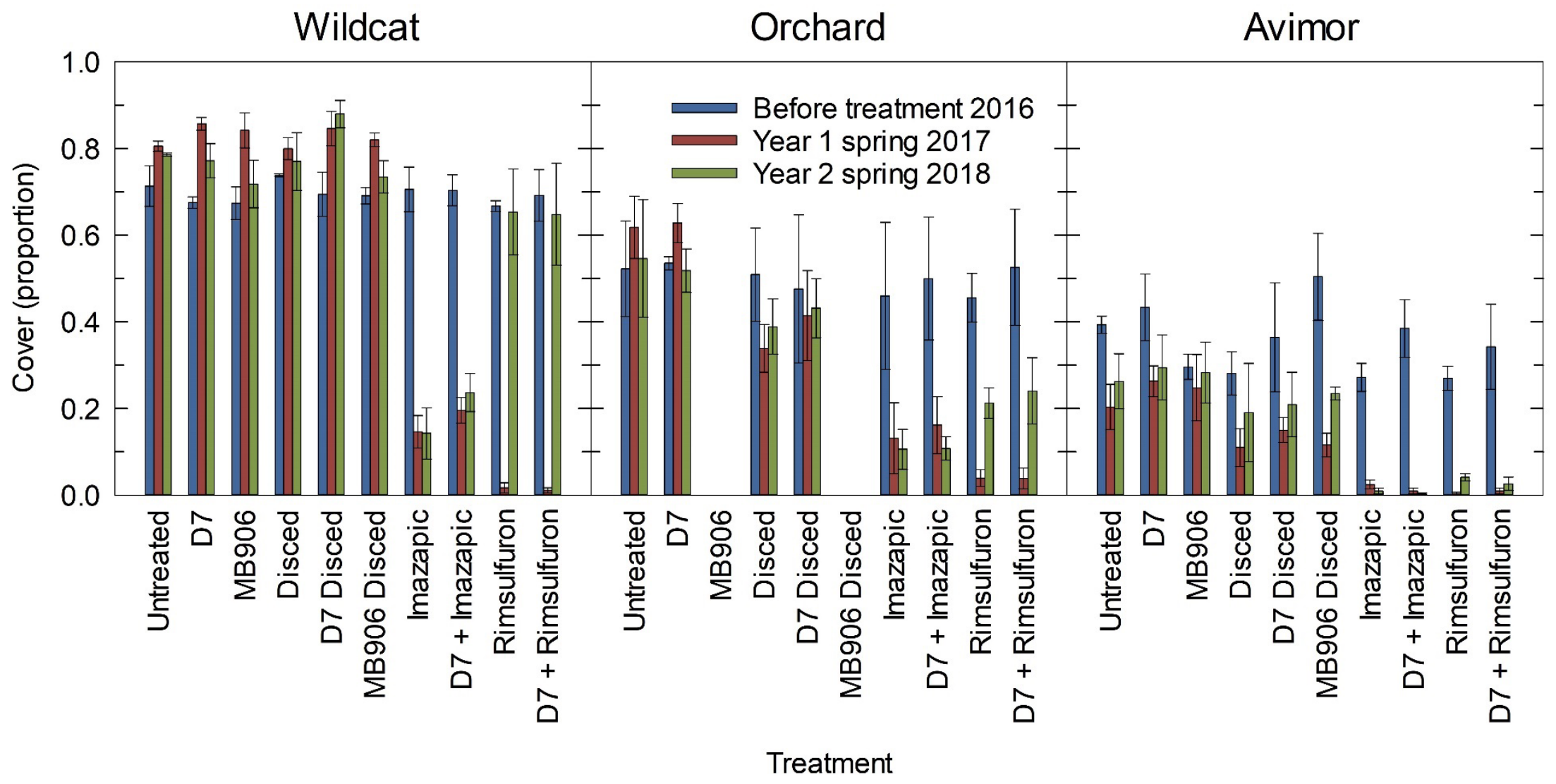

Figure 5. Graphs showing cover of invasive annual grasses targeted by weed-suppressive bacteria by Wildcat (left graph), Orchard (middle graph), and Avimor (right graph) study sites, southwestern Idaho, 2016-18. 


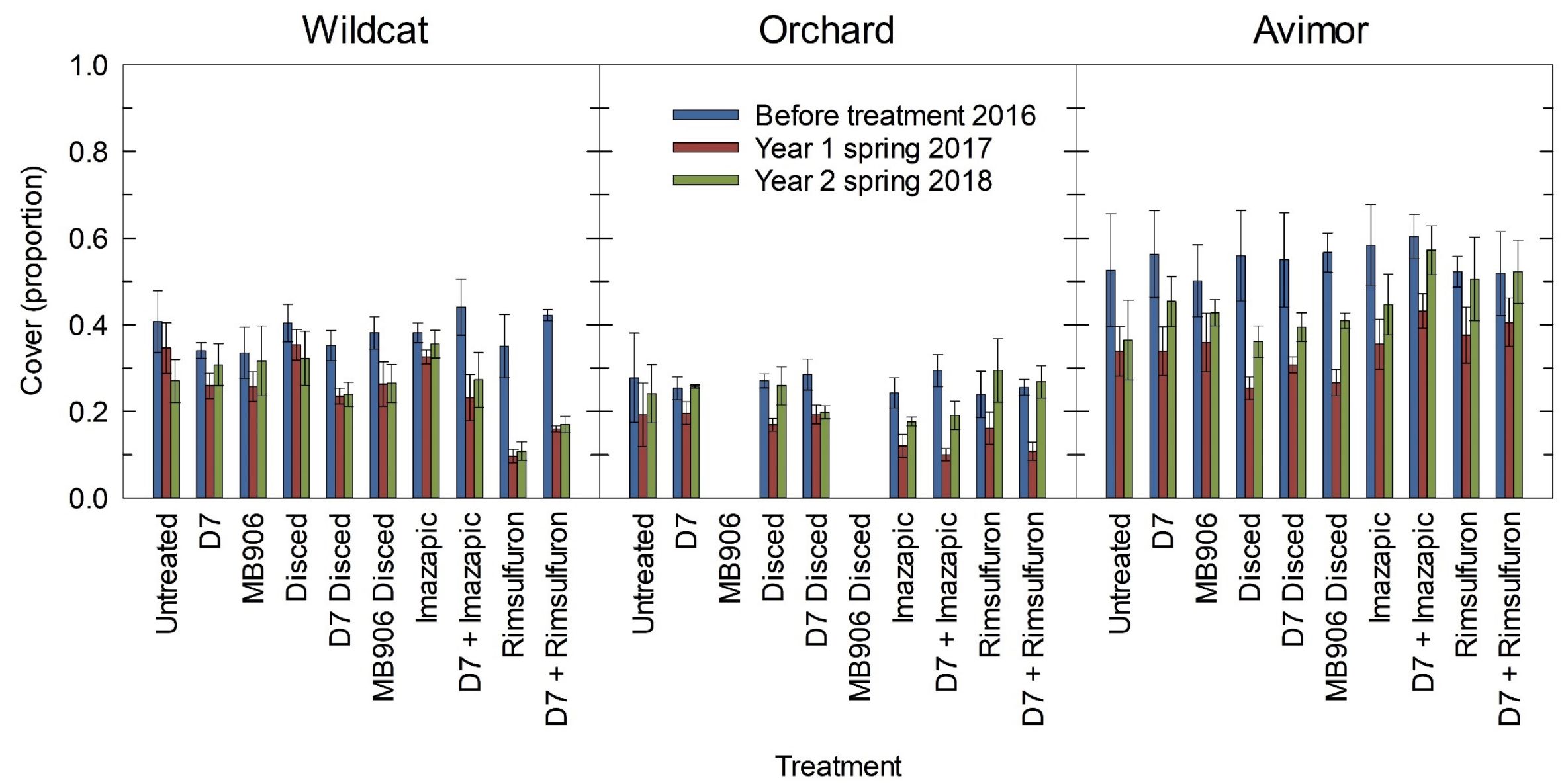

Figure 6. Graphs showing perennial grass cover by Wildcat (left graph), Orchard (middle graph), and Avimor (right graph) study sites, southwestern Idaho, 2016-18. 

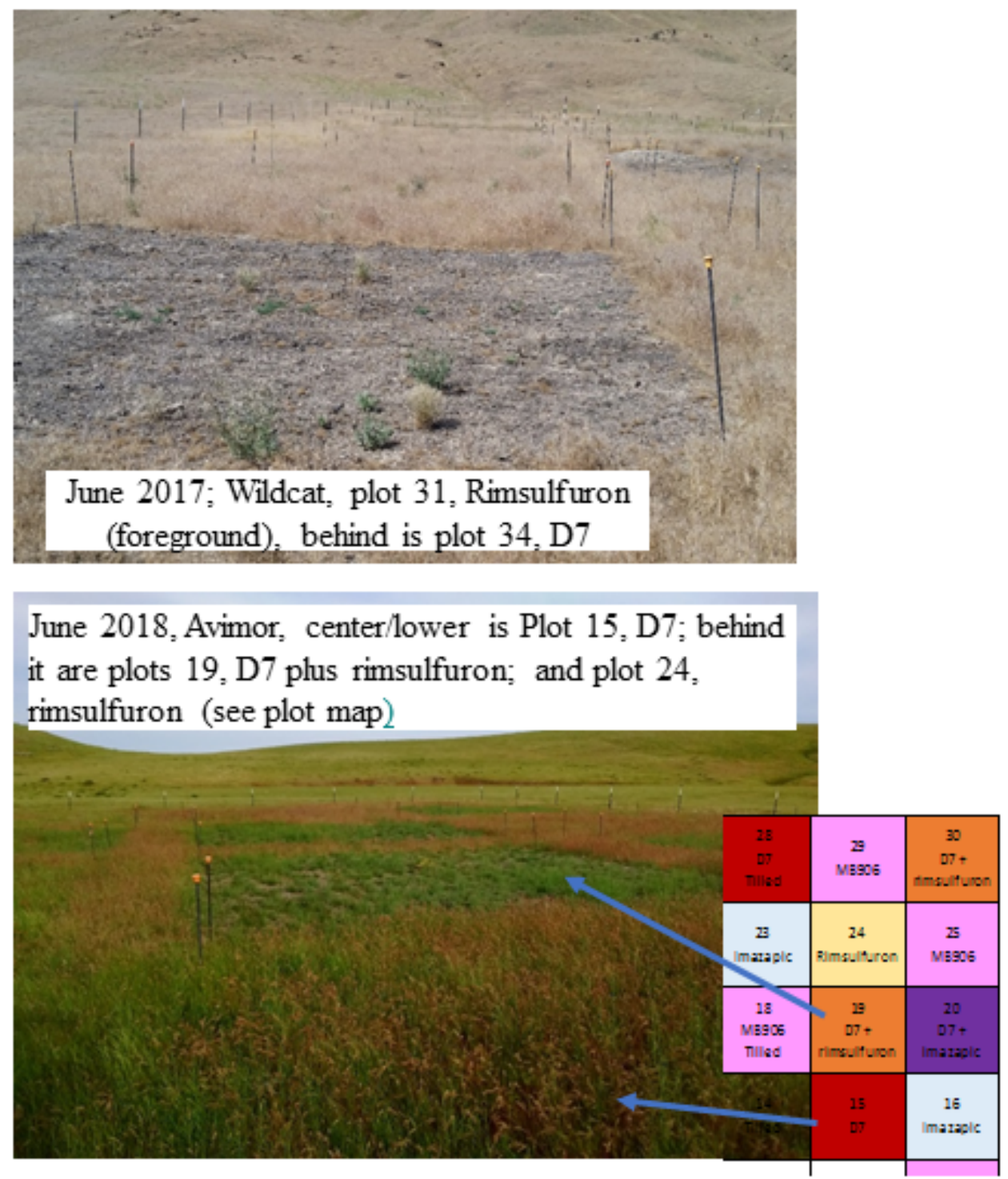

June 2018, Avimor, center/lower is Plot 15, D7; behind it are plots 19, D7 plus rimsulfuron; and plot 24 , rimsulfuron (see plot map)

Figure 7. Photographs showing representative plots at the Wildcat, Orchard, and Avimor study sites, southwestern Idaho. Photographs by Merry Davidson, U.S. Geological Survey, June 2017 (upper left photograph) and June 2018 (all other photographs). 
Table 1. Elevation, climate, soil texture and type, ownership, and plant community data at Wildcat, Avimor, and Orchard study sites, southwestern Idaho.

[Precipitation estimates are from Natural Resources Conservation Service web soil survey page (https://websoilsurvey.sc.egov.usda.gov/App/HomePage.htm). Soil textures are percent means (plus or minus standard error, in parentheses) of six samples per site measured using the hydrometer method (Bouyoucos, 1962). Abbreviations: m, meters above North American Vertical Datum of 1988; mm/yr, millimeter per year; \%, percentage]

\begin{tabular}{|c|c|c|c|c|c|c|c|c|}
\hline \multirow{2}{*}{ Site } & \multirow{2}{*}{$\begin{array}{l}\text { Elevation } \\
(\mathrm{m})\end{array}$} & \multirow{2}{*}{$\begin{array}{l}\text { Precipitation } \\
\text { (mm/yr) }\end{array}$} & \multicolumn{3}{|c|}{ Soil texture } & \multirow{2}{*}{ Soil type } & \multirow{2}{*}{ Ownership } & \multirow{2}{*}{ Plant community } \\
\hline & & & Sand (\%) & Silt (\%) & Clay (\%) & & & \\
\hline Wildcat & 808 & $152-254$ & $36(1)$ & $53(1)$ & $11(0.4)$ & Silt loam & State (Idaho) & $\begin{array}{l}\text { Sandberg bluegrass and } \\
\text { cheatgrass }\end{array}$ \\
\hline Orchard & 973 & $203-279$ & $46(2)$ & $46(2)$ & $8(0.6)$ & Loam & $\begin{array}{l}\text { Federal (Bureau } \\
\text { of Land } \\
\text { Management) }\end{array}$ & $\begin{array}{l}\text { Crested wheatgrass and } \\
\text { cheatgrass }\end{array}$ \\
\hline Avimor & 1,177 & $355-432$ & $56(2)$ & $32(1)$ & $12(0.9)$ & Sandy loam & Private & $\begin{array}{l}\text { Three-awn, medusahead, } \\
\text { and Ventenata dubia }\end{array}$ \\
\hline
\end{tabular}


Table 2. Weed-suppressive treatments applied at the three study sites, southwestern Idaho, autumn 2016.

[Treatments 2 and 3 were not applied at the Orchard site because MB906 is not approved for use on Federal lands]

\section{Treatments}

1. Untreated (control to treatments 2, 4, 6).

2. P. fluorescens MB906 sprayed on surface.

3. P. fluorescens MB906 incorporated in soil (by disc cut with rangeland drill seeder).

4. P. fluorescens D7 sprayed on surface.

5. P. fluorescens $\mathrm{D} 7$ incorporated in soil (same technique as treatment 3 ).

6. Disc only (control to treatments 3,5 ).

7. P. fluorescens $\mathrm{D} 7$ spray/applied after imazapic.

8. Imazapic sprayed only (control to treatment \#7).

9. P. fluorescens $\mathrm{D} 7$ spray/applied after rimsulfuron.

10.) Rimsulfuron only (control to treatment 9).

Table 3. Results of analysis of variance testing effects of site and treatment (D7, discing) on total foliar cover, invasive annual grass cover, and perennial bunchgrass cover at Wildcat, Avimor, and Orchard study sites, southwestern Idaho.

$\left[P\right.$ values less than $(<) 0.05$ are in bold text and indicate statistical significance. $P$ value, probability value; $r^{2}$, coefficient of determination]

\begin{tabular}{l|lcl}
\hline & \multicolumn{3}{|c}{$\begin{array}{c}\text { Cover of } \\
\text { invasive } \\
\text { annual } \\
\text { grasses } \\
\text { targeted by } \\
\text { D7 (including } \\
\text { subcanopy) }\end{array}$} \\
\begin{tabular}{l|cc} 
Cover of \\
perennial \\
bunchgrasses \\
(including \\
subcanopy)
\end{tabular} \\
\hline \multicolumn{1}{c|}{ Whole model $\boldsymbol{r}^{2}$} & \multicolumn{3}{|c}{0.84} \\
\hline \multicolumn{1}{c|}{ Source } & \multicolumn{3}{|c}{ Individual effect $\boldsymbol{P}$ values } \\
\hline Site & $<.0 .51$ \\
D7 & 0.92 & $<.0001$ & $\mathbf{0 . 0 0 0 7}$ \\
Site*D7 & 0.99 & 0.53 & 0.85 \\
Discing & $\mathbf{0 . 0 0 0 5}$ & 0.93 & 0.41 \\
Site*Discing & $<.0001$ & 0.23 & 0.50 \\
D7*Discing & 0.44 & 0.26 & 0.95 \\
Site*D7*Discing & 0.90 & 0.48 & 0.16 \\
\hline
\end{tabular}


Table 4A. Planned linear contrasts in total foliar cover by study site, southwestern Idaho, spring 2018 (year 2).

[Abbreviations: D7 and MB906, two strains of soil bacterium Pseudomonas fluorescens; DenDF, denominator degrees of freedom; DxM, Discing x MB906; F Ratio, ratio of two mean square values; Imaz, Imazapic; ImxD7, Imazapic x D7; NumDF, numerator degrees of freedom; Prob >F, probability is greater than F ratio; Rim, Rimsulfuron; RxD7, Rimsulfuron x D7; SS, sum of squares, Std Error, Standard Error]

\begin{tabular}{|c|c|c|c|c|}
\hline & Discing & MB906 & DxM & \\
\hline Control & 0.5 & 0.5 & 0.5 & \\
\hline MB906 & 0.5 & -0.5 & -0.5 & \\
\hline $\begin{array}{l}\text { MB906 + } \\
\text { Disced }\end{array}$ & -0.5 & -0.5 & 0.5 & \\
\hline Disced & -0.5 & 0.5 & -0.5 & \\
\hline Estimate & 0.0017 & $-3.00 E-04$ & 0.0017 & \\
\hline Std Error & 0.011 & 0.011 & 0.011 & \\
\hline t Ratio & 0.1515 & -0.03 & 0.1515 & \\
\hline Prob $>|t|$ & 0.8811 & 0.9761 & 0.8811 & \\
\hline ss & 8.30E-06 & 3.30E-07 & $8.30 \mathrm{E}-06$ & \\
\hline Ss & NumDF & DenDF & F Ratio & Prob $>F$ \\
\hline 2.00E-05 & 3 & 20 & 0.0156 & 0.9973 \\
\hline
\end{tabular}

\begin{tabular}{|c|c|c|c|c|}
\hline & Imaz & D7 & ImxD7 & \\
\hline Control & 0.5 & 0.5 & 0.5 & \\
\hline D7 & 0.5 & -0.5 & -0.5 & \\
\hline $\begin{array}{l}\text { D7 + } \\
\text { Imazapic }\end{array}$ & -0.5 & -0.5 & 0.5 & \\
\hline Imazapic & -0.5 & 0.5 & -0.5 & \\
\hline Estimate & 0.0767 & -0.005 & -0.001 & \\
\hline Std Error & 0.011 & 0.011 & 0.011 & \\
\hline t Ratio & 6.9681 & -0.424 & -0.091 & \\
\hline Prob $>|t|$ & $9.20 \mathrm{E}-07$ & 0.676 & 0.9285 & \\
\hline SS & 0.0176 & 0.0001 & 3.00E-06 & \\
\hline ss & NumDF & DenDF & F Ratio & Prob $>F$ \\
\hline 0.018 & 3 & 20 & 16.2475 & $<.0001$ \\
\hline Estimate & 0.509 & 0.0073 & -0.024 & \\
\hline Std Error & 0.0507 & 0.0507 & 0.0507 & \\
\hline t Ratio & 10.038 & 0.1446 & -0.48 & \\
\hline Prob $>|t|$ & $2.60 \mathrm{E}-08$ & 0.8868 & 0.6378 & \\
\hline SS & 0.7772 & 0.0002 & 0.0018 & \\
\hline SS & NumDF & DenDF & F Ratio & Prob $>F$ \\
\hline 0.779 & 3 & 16 & 33.6699 & $<.0001$ \\
\hline Estimate & 0.4843 & 0.004 & -0.012 & \\
\hline Std Error & 0.0257 & 0.0257 & 0.0257 & \\
\hline t Ratio & 18.838 & 0.1556 & -0.48 & \\
\hline Prob $>|t|$ & $3.00 \mathrm{E}-14$ & 0.8779 & 0.6366 & \\
\hline SS & 0.7037 & $4.80 \mathrm{E}-05$ & 0.0005 & \\
\hline SS & NumDF & DenDF & F Ratio & Prob $>F$ \\
\hline 0.704 & 3 & 20 & 118.372 & $<.0001$ \\
\hline
\end{tabular}

\begin{tabular}{|c|c|c|c|c|}
\hline & $\operatorname{Rim}$ & D7 & RxD7 & \\
\hline Control & 0.5 & 0.5 & 0.5 & \\
\hline D7 & 0.5 & -0.5 & -0.5 & \\
\hline D7 + Rim & -0.5 & -0.5 & 0.5 & \\
\hline Rim & -0.5 & 0.5 & -0.5 & \\
\hline Estimate & 0.0267 & -0.001 & -0.005 & \\
\hline Std Error & 0.011 & 0.011 & 0.011 & \\
\hline t Ratio & 2.4237 & -0.091 & -0.424 & \\
\hline Prob $>|t|$ & 0.025 & 0.9285 & 0.676 & \\
\hline SS & 0.0021 & $3.00 \mathrm{E}-06$ & 0.0001 & \\
\hline ss & NumDF & DenDF & F Ratio & Prob $>F$ \\
\hline 0.002 & 3 & 20 & 2.0208 & 0.1434 \\
\hline Estimate & 0.3213 & 0.0027 & -0.02 & \\
\hline Std Error & 0.0507 & 0.0507 & 0.0507 & \\
\hline t Ratio & 6.3369 & 0.0526 & -0.388 & \\
\hline Prob $>|t|$ & $9.90 \mathrm{E}-06$ & 0.9587 & 0.7032 & \\
\hline SS & 0.3098 & 2.10E-05 & 0.0012 & \\
\hline SS & NumDF & DenDF & F Ratio & Prob $>F$ \\
\hline 0.311 & 3 & 16 & 13.4366 & 0.0001 \\
\hline Estimate & 0.0512 & -0.009 & 0.0005 & \\
\hline Std Error & 0.0257 & 0.0257 & 0.0257 & \\
\hline t Ratio & 1.9901 & -0.344 & 0.0194 & \\
\hline Prob $>|t|$ & 0.0604 & 0.7348 & 0.9847 & \\
\hline SS & 0.0079 & 0.0002 & $7.50 \mathrm{E}-07$ & \\
\hline ss & NumDF & DenDF & F Ratio & Prob $>F$ \\
\hline 0.008 & 3 & 20 & 1.3596 & 0.2837 \\
\hline
\end{tabular}


Table 4B. Planned linear contrasts in cover of invasive annual grasses targeted by weed-suppressive bacteria by study site, southwestern Idaho, 2018 (year 2).

[Abbreviations: D7 and MB906, two strains of soil bacterium Pseudomonas fluorescens; DenDF, denominator degrees of freedom; DxM, Discing x MB906; F Ratio, ratio of two mean square values; Imaz, Imazapic; ImxD7, Imazapic x D7; NumDF, numerator degrees of freedom; Prob $>$ F, probability is greater than F ratio; Rim, Rimsulfuron; RxD7, Rimsulfuron x D7; SS, sum of squares, Std Error, Standard Error]

\begin{tabular}{|c|c|c|c|c|}
\hline & Discing & MB906 & DxM & \\
\hline Control & 0.5 & 0.5 & 0.5 & \\
\hline MB906 & 0.5 & -0.5 & -0.5 & \\
\hline $\begin{array}{l}\text { MB906 + } \\
\text { Disced }\end{array}$ & -0.5 & -0.5 & 0.5 & \\
\hline Disced & -0.5 & 0.5 & -0.5 & \\
\hline Estimate & 0.0797 & -0.054 & 0.0293 & \\
\hline Std Error & 0.073 & 0.073 & 0.073 & \\
\hline t Ratio & 1.092 & -0.738 & 0.4022 & \\
\hline Prob $>|t|$ & 0.2878 & 0.4693 & 0.6918 & \\
\hline SS & 0.019 & 0.0087 & 0.0026 & \\
\hline SS & NumDF & DenDF & F Ratio & Prob $>F$ \\
\hline 0.03 & 3 & 20 & 0.6328 & 0.6025 \\
\hline
\end{tabular}

\begin{tabular}{lrrr} 
& \multicolumn{1}{c}{ Imaz } & \multicolumn{1}{c}{ D7 } & ImxD7 \\
\hline Control & 0.5 & 0.5 & 0.5 \\
D7 & 0.5 & -0.5 & -0.5 \\
D7 + & -0.5 & -0.5 & 0.5 \\
Imazapic & -5 & & \\
Imazapic & -0.5 & 0.5 & -0.5 \\
\hline Estimate & 0.4851 & -0.005 & -0.029 \\
Std Error & 0.073 & 0.073 & 0.073 \\
t Ratio & 6.6492 & -0.072 & -0.397 \\
Prob>|t| & $\mathbf{1 . 8 0 E - 0 6}$ & 0.9437 & 0.6953 \\
SS & 0.706 & 0.0001 & 0.0025
\end{tabular}

\begin{tabular}{lrrr} 
& \multicolumn{1}{c}{ Rim } & \multicolumn{1}{c}{ D7 } & RxD7 \\
\hline Control & 0.5 & 0.5 & 0.5 \\
D7 & 0.5 & -0.5 & -0.5 \\
D7 + Rim & -0.5 & -0.5 & 0.5 \\
Rim & -0.5 & 0.5 & -0.5 \\
\hline Estimate & 0.3732 & 0.0093 & -0.044 \\
Std Error & 0.073 & 0.073 & 0.073 \\
t Ratio & 5.1151 & 0.1279 & -0.597 \\
Prob>|t| & $\mathbf{0 . 0 0 0 1}$ & 0.8995 & 0.5573 \\
SS & 0.4178 & 0.0003 & 0.0057
\end{tabular}

SS NumDF DenDF F Ratio Prob $>F$

\begin{tabular}{lllll}
0.03 & 3 & 20 & 0.6328 & 0.6025 \\
\hline
\end{tabular}

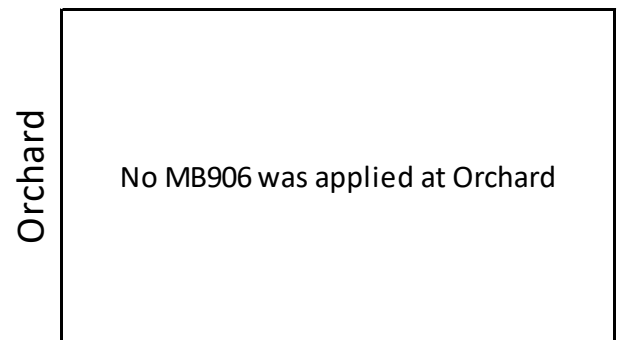

$\begin{array}{lllll}0.709 & 3 & 20 & 14.792 & <.0001\end{array}$

SS NumDF DenDF F Ratio Prob > F

\begin{tabular}{|rrrrr}
0.709 & & 20 & 14.792 & $<.0001$ \\
\hline Estimate & 0.5002 & 0.0041 & 0.0253
\end{tabular}

Std Error $\quad 0.0801 \quad 0.0801 \quad 0.0801$

$\begin{array}{llll}\text { Ratio } & 6.2481 & 0.0506 & 0.3167\end{array}$

Prob $>|t| \quad$ 1.20E-05 $0.9602 \quad 0.7556$

SS

0.7505 4.90E-05 0.0019

SS NumDF DenDF F Ratio Prob $>F$

\begin{tabular}{|c|c|c|c|c|}
\hline Estimate & -0.002 & 0.0608 & 0.0142 & \\
\hline Std Error & 0.0735 & 0.0735 & 0.0735 & \\
\hline t Ratio & -0.026 & 0.8269 & 0.1931 & \\
\hline Prob $>|t|$ & 0.9799 & 0.418 & 0.8488 & \\
\hline SS & 1.10E-05 & 0.0111 & 0.0006 & \\
\hline SS & NumDF & DenDF & F Ratio & Prob $>$ F \\
\hline 0.012 & 3 & 20 & 0.2406 & 0.867 \\
\hline
\end{tabular}

\begin{tabular}{|lrrrr|}
\hline \multicolumn{1}{|r}{0.752} & 3 & 16 & 13.047 & $<.0001$ \\
\hline Estimate & 0.6439 & -0.058 & 0.0727 & \\
Std Error & 0.0735 & 0.0735 & 0.0735 & \\
t Ratio & 8.7546 & -0.788 & 0.9882 & \\
Prob $>|t|$ & $2.80 E-08$ & 0.4399 & 0.3349 & \\
SS & 1.2437 & 0.0101 & 0.0158 & \\
& & & & \\
SS & NumDF & DenDF F Ratio & Prob $>$ F \\
1.27 & 3 & 20 & 26.08 & $<.0001$ \\
\hline
\end{tabular}

\begin{tabular}{|c|c|c|c|c|}
\hline 0.424 & 3 & 20 & 8.8456 & 0.0006 \\
\hline Estimate & 0.3286 & 0.0009 & 0.0285 & \\
\hline Std Error & 0.0801 & 0.0801 & 0.0801 & \\
\hline t Ratio & 4.1043 & 0.0114 & 0.3559 & \\
\hline Prob $>|t|$ & 0.0008 & 0.991 & 0.7266 & \\
\hline SS & 0.3238 & 2.50E-06 & 0.0024 & \\
\hline SS & NumDF & DenDF & F Ratio & Prob $>F$ \\
\hline 0.326 & 3 & 16 & 5.6572 & 0.0077 \\
\hline Estimate & 0.1344 & 0.0056 & 0.0091 & \\
\hline Std Error & 0.0735 & 0.0735 & 0.0735 & \\
\hline t Ratio & 1.8274 & 0.0763 & 0.1237 & \\
\hline Prob $>|t|$ & 0.0826 & 0.9399 & 0.9028 & \\
\hline SS & 0.0542 & 0.0001 & 0.0002 & \\
\hline
\end{tabular}

SS NumDF DenDF F Ratio Prob > F

\begin{tabular}{lllll}
0.055 & 3 & 20 & 1.1202 & 0.3645 \\
\hline
\end{tabular}


Table 4C. Planned linear contrasts in cover of perennial grasses by study site, southwestern Idaho, spring 2018 (year 2).

[Abbreviations: D7 and MB906, two strains of soil bacterium Pseudomonas fluorescens; DenDF, denominator degrees of freedom; DxM, Discing x MB906; F Ratio, ratio of two mean square values; Imaz, Imazapic; ImxD7, Imazapic x D7; NumDF, numerator degrees of freedom; Prob >F, probability is greater than F ratio; Rim, Rimsulfuron; RxD7, Rimsulfuron x D7; SS, sum of squares, Std Error, Standard Error]

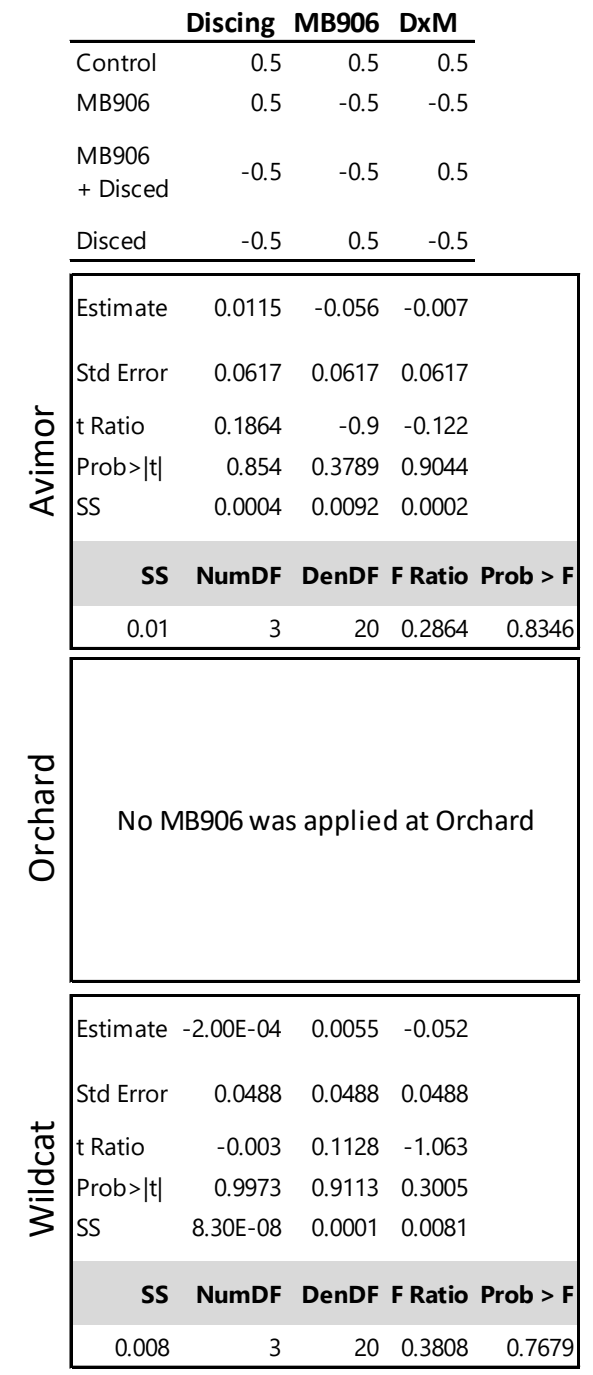

\begin{tabular}{|c|c|c|c|c|}
\hline & Imaz & D7 & ImxD7 & \\
\hline Control & 0.5 & 0.5 & 0.5 & \\
\hline D7 & 0.5 & -0.5 & -0.5 & \\
\hline $\begin{array}{l}\text { D7 + } \\
\text { Imazapic }\end{array}$ & -0.5 & -0.5 & 0.5 & \\
\hline Imazapic & -0.5 & 0.5 & -0.5 & \\
\hline Estimate & -0.1 & -0.107 & 0.0183 & \\
\hline Std Error & 0.0617 & 0.0617 & 0.0617 & \\
\hline t Ratio & -1.616 & -1.74 & 0.2972 & \\
\hline $\operatorname{Prob}>|t|$ & 0.1218 & 0.0972 & 0.7694 & \\
\hline \multirow[t]{2}{*}{ SS } & 0.0298 & 0.0346 & 0.001 & \\
\hline & NumDF & DenDF & F Ratio & Prob $>$ F \\
\hline 0.065 & 3 & 20 & 1.9092 & $\begin{array}{l}2 \\
2\end{array}$ \\
\hline Estimate & 0.0657 & -0.016 & -0.001 & \\
\hline Std Error & 0.0429 & 0.0429 & 0.0429 & \\
\hline t Ratio & 1.5311 & -0.365 & -0.023 & \\
\hline Prob $>|t|$ & 0.1453 & 0.7197 & 0.9817 & \\
\hline \multirow[t]{2}{*}{ SS } & 0.0129 & 0.0007 & $3.00 \mathrm{E}-06$ & \\
\hline & NumDF & DenDF & F Ratio & Prob $>F$ \\
\hline 0.014 & 3 & 16 & 0.8261 & $\begin{array}{l}0.4986 \\
\end{array}$ \\
\hline Estimate & -0.025 & 0.0225 & -0.06 & \\
\hline Std Error & 0.0488 & 0.0488 & 0.0488 & \\
\hline t Ratio & -0.509 & 0.4614 & -1.234 & \\
\hline Prob $>|t|$ & 0.6162 & 0.6495 & 0.2316 & \\
\hline \multirow[t]{2}{*}{ SS } & 0.0019 & 0.0015 & 0.0109 & \\
\hline & NumDF & DenDF & F Ratio & Prob $>F$ \\
\hline 0.014 & 3 & 20 & 0.6647 & 0.5835 \\
\hline
\end{tabular}

\begin{tabular}{|c|c|c|c|c|}
\hline & Rim & D7 & RxD7 & \\
\hline Control & 0.5 & 0.5 & 0.5 & \\
\hline D7 & 0.5 & -0.5 & -0.5 & \\
\hline $\mathrm{D} 7$ + Rim & -0.5 & -0.5 & 0.5 & \\
\hline $\operatorname{Rim}$ & -0.5 & 0.5 & -0.5 & \\
\hline Estimate & 0.0115 & -0.056 & -0.007 & \\
\hline Std Error & 0.0617 & 0.0617 & 0.0617 & \\
\hline t Ratio & 0.1864 & -0.9 & -0.122 & \\
\hline Prob $>|t|$ & 0.854 & 0.3789 & 0.9044 & \\
\hline \multirow[t]{2}{*}{ SS } & 0.0004 & 0.0092 & 0.0002 & \\
\hline & NumDF & DenDF & F Ratio & Prob $>F$ \\
\hline 0.01 & 3 & 20 & 0.2864 & 0.8346 \\
\hline Estimate & 0.0657 & -0.016 & -0.001 & \\
\hline Std Error & 0.0429 & 0.0429 & 0.0429 & \\
\hline t Ratio & 1.5311 & -0.365 & -0.023 & \\
\hline Prob $>|t|$ & 0.1453 & 0.7197 & 0.9817 & \\
\hline \multirow[t]{2}{*}{ SS } & 0.0129 & 0.0007 & $3.00 E-06$ & \\
\hline & NumDF & DenDF & F Ratio & Prob $>F$ \\
\hline 0.014 & 3 & 16 & 0.8261 & 0.4986 \\
\hline Estimate & 0.1505 & -0.05 & 0.0122 & \\
\hline Std Error & 0.0488 & 0.0488 & 0.0488 & \\
\hline t Ratio & 3.0859 & -1.022 & 0.2495 & \\
\hline Prob $>|t|$ & 0.0058 & 0.3191 & 0.8055 & \\
\hline \multirow[t]{2}{*}{ SS } & 0.068 & 0.0075 & 0.0004 & \\
\hline & NumDF & DenDF & F Ratio & Prob $>F$ \\
\hline 0.076 & 3 & 20 & 3.5431 & 0.0332 \\
\hline
\end{tabular}



Publishing support provided by the U.S. Geological Survey Science Publishing Network, Tacoma Publishing Service Center

For more information concerning the research in this report, contact the Director, Forest and Rangeland Ecosystem Science Center

U.S. Geological Survey

777 NW 9th St., Suite 400

Corvalis, Oregon 97330

https://www.usgs.gov/centers/fresc/ 
